\title{
Southwestern Pottery and Turquoise in Northeastern Texas
}

David H. Jurney

Unknown

William Young

Follow this and additional works at: https://scholarworks.sfasu.edu/ita

Part of the American Material Culture Commons, Archaeological Anthropology Commons, Environmental Studies Commons, Other American Studies Commons, Other Arts and Humanities Commons, Other History of Art, Architecture, and Archaeology Commons, and the United States History Commons

Tell us how this article helped you.

This Article is brought to you for free and open access by the Center for Regional Heritage Research at SFA ScholarWorks. It has been accepted for inclusion in Index of Texas Archaeology: Open Access Gray Literature from the Lone Star State by an authorized editor of SFA ScholarWorks. For more information, please contact cdsscholarworks@sfasu.edu. 


\section{Southwestern Pottery and Turquoise in Northeastern Texas}

Creative Commons License

(c) (i) (8)

This work is licensed under a Creative Commons Attribution-NonCommercial 4.0 International License 


\title{
SOUTHWESTERN POTTERY AND TURQUOISE IN NORTHEASTERN TEXAS
}

\author{
David H. Jurney and William Young \\ [Paper presented at the 37th (1995) Caddo Conference, Austin, Texas]
}

\begin{abstract}
Rare and often questionable occurrences of southwestern pottery and turquoise artifacts have been reported in northeastern Texas. These artifacts may mark major interaction networks. Both southwestern pottery and turquoise artifacts have been found at the Sanders site, which is located in the core distribution of these "erratics."
\end{abstract}

\section{Introduction}

Southwestern pottery types and turquoise artifacts are rare occurrences in the Caddoan area, yet northeastern Texas has several reported finds. The majority of these have been collected, reported, and curated by avocational archaeologists (Figure 1). Many such finds are thought to ultimately derive from the southwest, yet the empirical evidence associated with their discovery and, in some cases, the items themselves, are lost to posterity. To set this problem in focus, we decided to pool our knowledge of finds of exotic southwestern pottery and turquoise; from both avocational collections and the literature. Data drawn from archaeological sites across the Southern Plains and the Trans-Mississippi South are used to examine the timing and spacing of Southwestern-Caddoan interactions.

Strategic resources in this exchange are thought to be bison hides, meat, hair rope and textiles (Creel 1991:40-42) from the Plains; salt and bow wood from the Caddos (Schambach 1993; Jeter et al. 1994); and turquoise and cotton blankets from the Southwestern Pueblos (Swanton 1942:37). Southwestern pottery is not mentioned in historical accounts, but it also played a role; possibly in the exchange of seed maize.

Occurrences of southwestern pottery vessels or turquoise artifacts in northeastern Texas, were discussed by Kreiger (1946). We have not progressed much farther than he in the interpretation of this important aspect of prehistoric interregional trade. However, some incidental scientific finds have been noted since then, providing additional direct associations between Southwestern and Caddoan peoples. Also, direct geophysical methods of sourcing pottery and turquoise that were developed in the interim add to the empirical evidence for the origin of materials and artifacts.

Recent discussions (Schambach 1993; Jeter $e t$ al. 1994; Wilson 1993, 1994) have indicated the potential existence of Spiroan trade networks between the Southwest, Plains, and Lower 


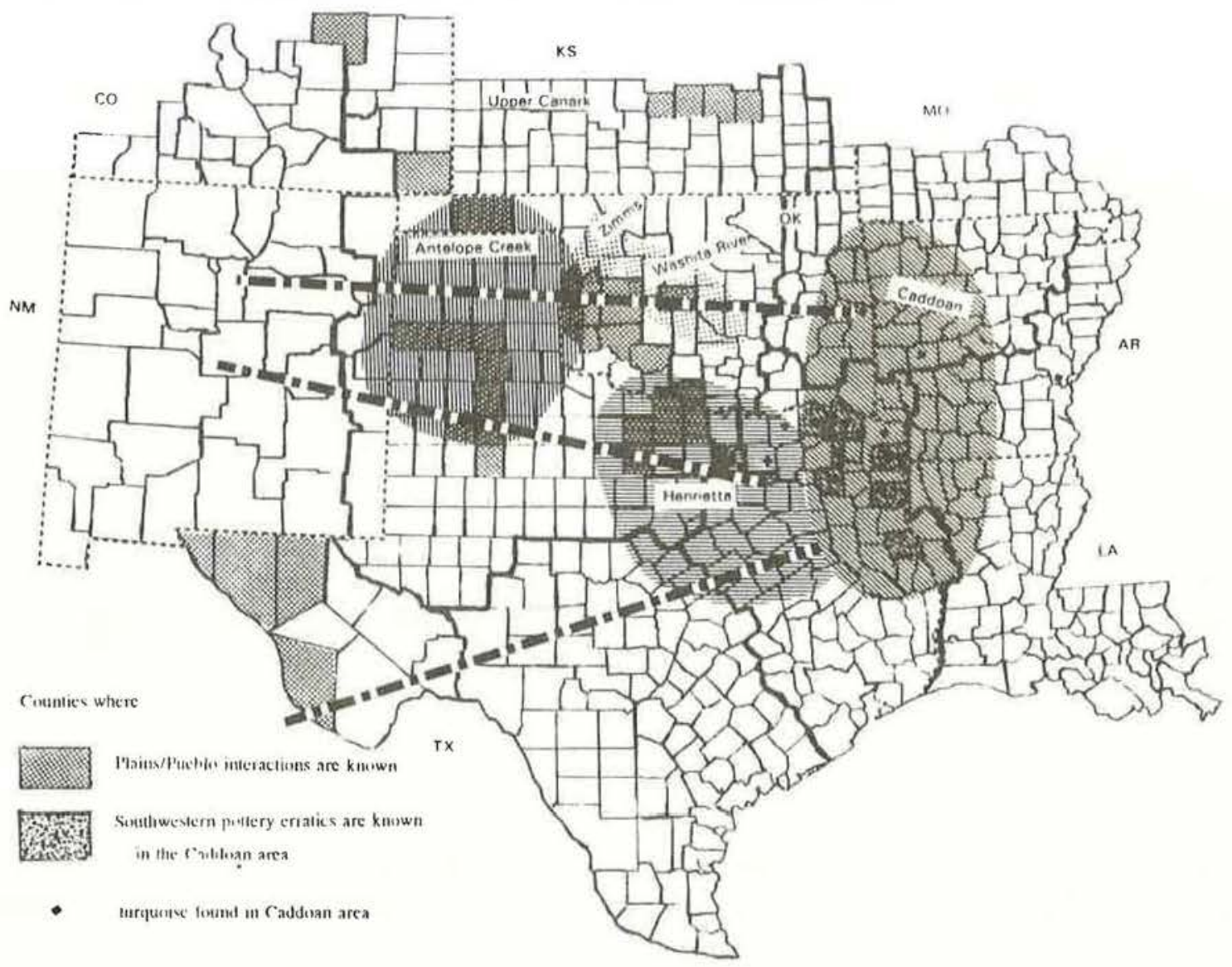

Figure 1. Locations Where Plains/Pueblo Interactions are Known, and Where Southwestern Pottery Erratics and Turquoise are Known in the Caddoan Area.

Mississippi Valley, with overland connections between the Red River and Arkansas River. Apparently overland trails extended west to the Rio Grande Pueblos. The Sanders site is the principal candidate for such an entrepôt in northeastern Texas, and it is predicted that the distribution of known turquoise and southwestern pottery will center around the Sanders site.

\section{Southwestern Pottery Distributions Among Archaeological Complexes}

Some southern High Plains archaeological complexes (Table 1) have been reported to contain low to moderate amounts of southwestern sherds, turquoise, and obsidian (Kreiger 1946; Brooks 1989; Hofman 1989). The estimated dates begin $c a$. A.D. 940 with the Upper Canark
Complex. The Antelope Creek Complex of the Texas Panhandle and the Washita River Complex of Oklahoma (Figure 1) date ca. 1200-1450, along with the Zimms Complex ca. 1265-1425 of western Oklahoma. This marks the firm establishment of a native Plains-Pueblo interaction, 
Table 1. Archaeological Complexes across the Southern High Plains that Possess Southwestern Pottery, Turquoise, and Occasionally Obsidian; Suggestive of a Bison Products-Maize Exchange System*.

\begin{tabular}{llll}
\hline $\begin{array}{l}\text { Archaeological } \\
\text { Complex }\end{array}$ & Inner & $\begin{array}{r}\text { Dating } \\
\text { (A.D.) } \\
\text { Outer }\end{array}$ & Region \\
Upper Canark & & & \\
Antelope Creek $^{2}$ & 940 & 1500 & CO,NM,TX,OK \\
Washita River $^{3}$ & 1200 & 1500 & NWTX \\
Zimms $^{4}$ & 1250 & 1450 & OK \\
Henrietta $^{5}$ & 1265 & 1425 & WOK \\
Tierra Blanca & & 1575 & TX \\
Edwards $^{7}$ & 1400 & 1650 & NM,OK,TX \\
Wheeler $^{8}$ & 1500 & 1650 & WOK \\
Garza $^{9}$ & 1650 & 1725 & OK \\
Great Bend Aspect & 1500 & 1650 & OK,TX \\
\hline \hline
\end{tabular}

- (after Brooks 1989 and Hofman 1989)

1 Lintz 1986; ${ }^{2}$ Lintz 1986; ${ }^{3}$ Bell 1984a; ${ }^{4}$ Flynn 1986; ${ }^{5}$ Kreiger 1946;

${ }^{6}$ Habiche-Mauche 1987; ${ }^{7}$ Baugh 1982, 1986; ${ }^{8}$ Bell and Bastian 1967, Hofman 1978, 1989; ${ }^{2}$ Baugh 1986, Hofman 1989, Johnson et al. 1977; ${ }^{10}$ Wedel 1982, 1986

which continued into the Henrietta Complex of Texas ca. 1575; the Terra Blanca Complex of New Mexico, Oklahoma, and Texas ca. 14001650; and the Garza Complex of Oklahoma and Texas ca. 1500-1650 (Habiche-Mauche 1987; Brooks 1989; Hofman 1989). Whole and reconstructible southwestern vessels, primarily jars and bottles, are frequently found along permanent rivers or cached at springs (Spielmann 1982:318). This movement of rare, yet appar- ently highly curated, exotics was apparently achieved without the horse. The Wheeler (16501725) Complex of Oklahoma (Hofman 1978) and the Great Bend Aspect (1540-1750) of Kansas and Oklahoma also contain southwestern materials, but were influenced by the addition of the horse to the trading and exchange network.

The Rio Grande Glaze Periods, Tewa Polychromes, El Paso Polychromes and Brownwares, 
Three Rivers Red-on-Terracotta, and Lincoln Brownware are commonly found in Upper Canark (940-1500) and Antelope Creek (12001500) contexts across the Llano Estacado, and Concepçion Focus (1583-1650) contexts of the Trans-Pecos region (Kreiger 1946:209; Brooks 1989; Hofman 1989) of western Texas (Table 2). There appears to be a gap in the distribution of these erratic exotics from Montaque County to Rockwall County in northern Texas.

Dan Prikryl, in his analysis of R. King Harris' collections in the Smithsonian, notes Southwestern sherds (untyped) at Hickory Creek (41DN49) and 41DN353, in Denton County, Texas (Prikryl 1990). "Types" which have been found as erratics in the Caddoan area include sherds identified as Chupadero (southern New Mexico), dating from the 12-15th centuries are common on Henrietta (Wichita?) sites in Clay and Montague counties. They are also noted in the Young family's collections at the Sanders Site in Lamar County on Bois d'Arc Creek and the Red River, and the Hughes collection from Shelby County on the Sabine River (Kreiger 1946:208). "Upper Gila" (Arizona), brown corrugated wares dating to the 15 th $\mathrm{C}$. were identified by H. P. Mera and described by Kreiger in his examination (?) of the Hughes collection from the Sanders Site on Red River (Kreiger 1946:208). The "Chupadero" identification of the specimens collected by Young as well as those in the Hughes collection need to be reexamined by current typologists. "Mogollon brownware," ascribed to the Tonto Region. Arizona was identified from Harrison County (Hayner 1955:245). A nearly whole vessel (Figure 2) was found on Aud's Creek, near Paris in Lamar County; however H. P. Mera identified it (by photographs) as Zuni dating to the mid-19th century (Wright 1943:92-95). This specimen certainly merits reexamination if it can be located. Unidentified southwestern sherds were reported from Cass and Franklin counties by Kreiger, but the collections were unspecified (Kreiger 1946:208). The Dieckman collection (the same examined by Kreiger?) from the Hayes Farm (41FK8) in Franklin County reportedly contains Gila Polychrome, Tonto Polychrome, Maverick Mountain Redware, dating $c a$. A. D. 1250-1450 (Thurman 1990:60). The Steck site, in Wood County, Texas, yielded a neck-banded ware which appears to derive from the Southwest (Timothy K. Perttula, personal communication 1995).

An important, but generally overlooked, find is the stirrup-spout vessel recovered from the SMU salvage excavation of the Lower Rockwall site, typed Arboles Black-on-White (AD 950-1050), and thought at the time to be derived from the Navajo Reservation area of northwestern New Mexico (Lorrain and Hoffrichter 1968). The stirrup-spout bottle (Figure 3) was recovered from Backhoe Trench 1 at the Lower Rockwall site (essentially the only excavation in the eastern half of the site, the western half contained a "Wylie focus pit," which received greater attention), about $1 \mathrm{~m}$ below ground surface in the rich black waxy of the East Fork Trinity River floodplain. The vessel is nearly whole, missing only the neck of the stirrup. It is rock tempered with a black-on-white painted design on the upper half. It appeared to be coated with a fine-textured organic deposit in the field, which was scrubbed off in the laboratory. Initial analysis by Kathleen Gilmore indicated a southwestern origin, confirmed by A. E. Dittert Jr. (Lorrain and Hoffrichter 1968:53-57). Numerous eccentric vessels were produced in northwestern New Mexico and southwestern Colorado during Pueblo I, but the 950-1050 date for Arboles Black-on White places the vessel in Pueblo II times; necessitating the assumption that these eccentric vessels continued in use (Lorrain and Hoffrichter 1968:56). 
Table 2. Southwestern Pottery Types Found on Caddoan Sites in Northern Texas, Based on Literature Searches and Examination of Avocational and Archaeological Collections.

\begin{tabular}{|c|c|c|c|}
\hline Pottery Type & Source & Distribution & Dates A.D. \\
\hline Arboles $\mathbf{B} / \mathbf{W}^{1}$ & NWNM & Lower Rockwall & $950-1050$ \\
\hline Chupadero $^{2}$ & NM & Clay, Montague, Lamar, Shelby & $1300-1400$ \\
\hline Rio Grande $I^{3}$ & NM & Llano Estacado/Trans Pecos & $1375-1425$ \\
\hline Rio Grande II $^{4}$ & NM & Llano Estacado/Trans Pecos & $1425-1475$ \\
\hline Rio Grande III $^{5}$ & NM & Llano Estacado/Trans Pecos & $1475-1550$ \\
\hline Rio Grande IV ${ }^{6}$ & NM & Llano Estacado/Trans Pecos & $1550-1650$ \\
\hline Rio Grande $V^{7}$ & NM & Llano Estacado/Trans Pecos & $1650-1750$ \\
\hline Upper Gila $^{8}$ & $\mathbf{A Z}$ & Lamar, Red River & 1600 \\
\hline Mogollon Brownware & $\begin{array}{l}\text { Tonto } \\
\text { AZ }\end{array}$ & Harrison & $?$ \\
\hline Tewa Polychrome ${ }^{10}$ & TX,NM & Llano Estacado/Trans Pecos & $?$ \\
\hline El Paso Poly chrome ${ }^{11}$ & TX,NM & Llano Estacado/Trans Pecos & $?$ \\
\hline El Paso Brownware ${ }^{12}$ & TX,NM & Llano Estacado/Trans Pecos & $?$ \\
\hline $\begin{array}{l}\text { Three Rivers } \\
\text { Red/Terracotta }\end{array}$ & TX,NM & Llano Estacado/Trans Pecos & $?$ \\
\hline Lincoln Bl./ $\mathbf{R}^{14}$ & TX,NM & Llano Estacado/Trans Pecos & $?$ \\
\hline "Zuni"15 & NM & Lamar & 1850 \\
\hline Unidentified $^{16}$ & SW & Franklin, Cass & $?$ \\
\hline
\end{tabular}

${ }^{1}$ Lorrain \& Hoffrichter 1968; ${ }^{2}$ Kreiger 1946:162, 207-208; ${ }^{3}$ Kreiger 1946:83, Wedel 1982, Hofman et al. 1989; ${ }^{4}$ Wedel 1982, Hofman et al. 1989; ${ }^{5}$ Wedel 1982, Hofman et al. 1989; ${ }^{6}$ Wedel 1982, Hofman et al. 1989; ${ }^{7}$ Wedel 1982, Hofman et al. 1989; ${ }^{8}$ H.P. Mera; ${ }^{9}$ Kreiger 1946:208; ${ }^{10}$ Kreiger 1946:143; ${ }^{11}$ Kreiger 1946:143; ${ }^{12}$ Kreiger 1946:143; ${ }^{13}$ Kreiger 1946:143; ${ }^{14}$ Kreiger 1946:143; ${ }^{15}$ Wright 1943; ${ }^{16}$ Kreiger 1946:208 

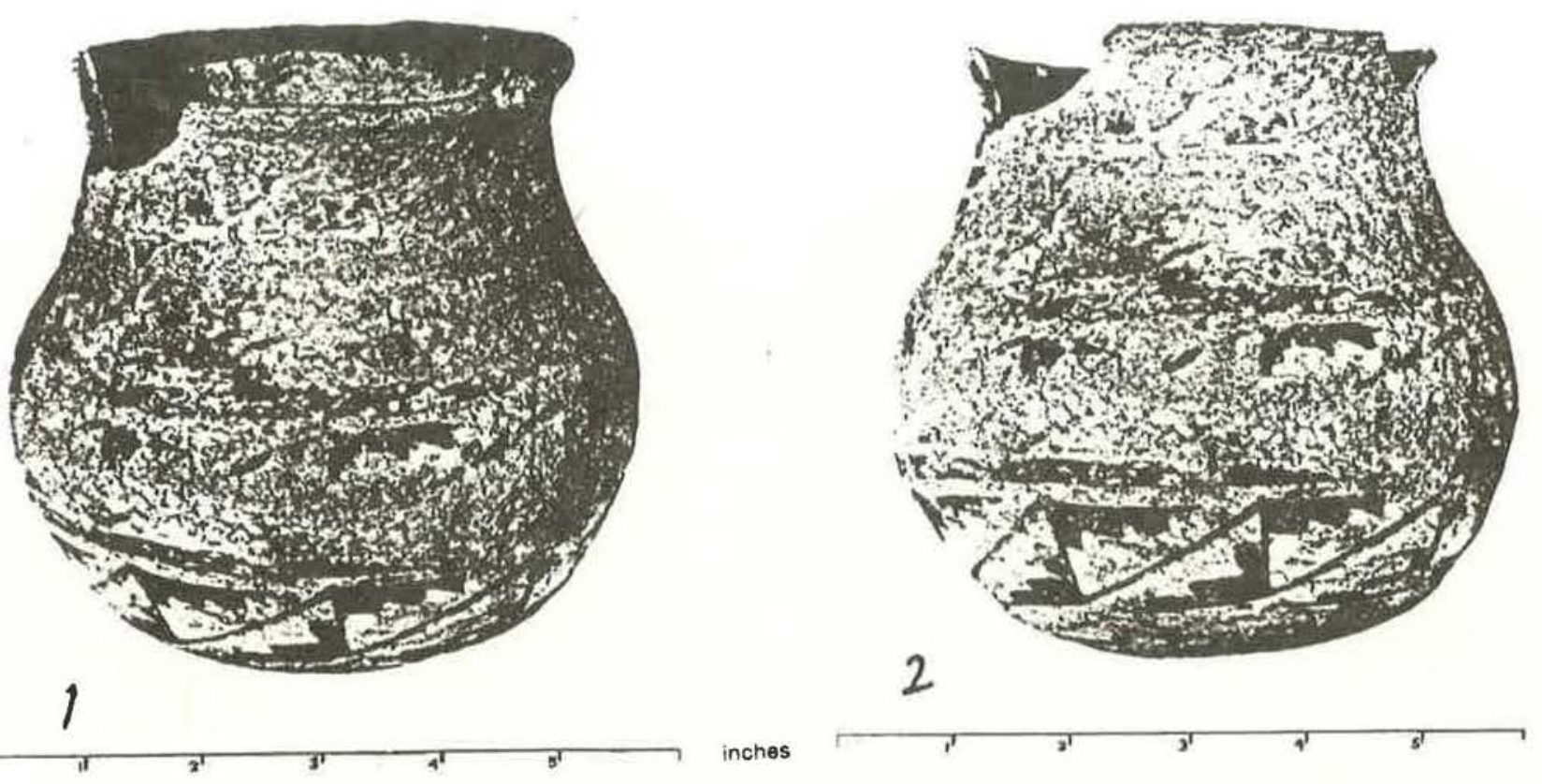

Figure 2. A Southwestern Pot from Aud's Creek, near Paris in lamar County, Typed as Mid-nineteenth Century Zuni (Wright 1943).

\section{Southwestern Pottery Sourcing}

Petrographic Analysis. The analysis of the temper in this vessel was stimulated by research on "Wylie Focus" sites in the Richland/Chambers Reservoir project (McIntyre and McGregor 1982; Irvine, in Bruseth 1987:116). It was thin sectioned and a petrographic analysis performed by the SMU Geology Department in 1981 as a part of the regional background study for the Richland Chambers Reservoir (McIntyre and McGregor 1982; Irvine in Bruseth 1987: 116). This analysis confirmed that the basalt temper came from the upper Rio Grande of New Mexico. Because this report (McIntyre and McGregor 1982) received limited distribution, the results will be summarized here.

The vessel sample consisted of $55-60 \%$ reddish brown clay fragments; $35 \%$ weathered basalt fragments and monocrystalline fragments of olivine, pyroxene and plagioclase derived from basalt (200-700 micron size range); $5 \%$ opagues, probably magnetite and hematite; $1-2 \%$ calcite of unknown affinity; and $1 \%$ quartz, extremely rare, always in the matrix. Single crystal size for the plagioclase, olivine, and pyroxene fragments ranges up to 600 microns. Grit used was weathered basalt. Some calcite was either added as a 


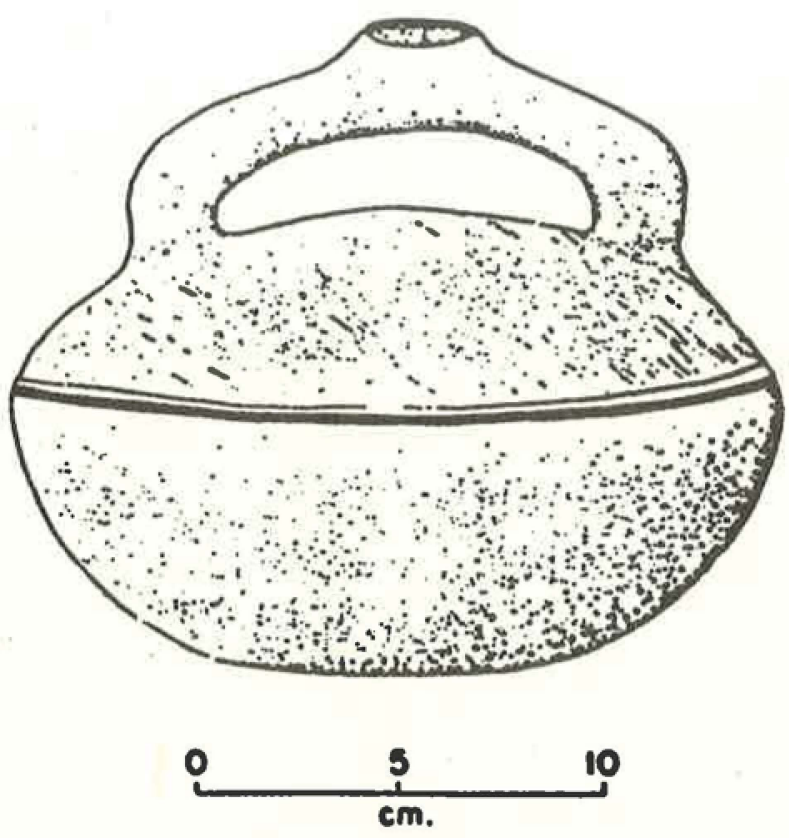

Figure 3. A Reconstructed Stirrup-spout Pot from the Lower Rockwall Site on the East Fork Trinity River, Typed as Arboles Black-on-White (A.D. 950-1050; Lorrain and Hoffrichter 1968). flux (?) or is accidental inclusion of limestone and caliche. Almost no basaltic rocks in the area (northern Texas). There are a few 1-2 mile wide plugs near Austin and a few plugs in central Arkansas. It does not make sense that they would use weathered basalt if they were near any other source of grit, and in the areas around the plugs in Arkansas and near Austin there is abundant quartz sand nearby. Also there are almost no quartz crystals at all. The materials near the plugs near Austin and Arkansas would almost certainly be more contaminated. The source of the basalt fragment grit could not have been more than a few miles from the basalt outcrop, (because) olivine, pyroxene, and calcic plagioclases are extremely unstable in a stream environment. The nearest source of basalt other than the ones mentioned above is the Rio Grande valley (Big Bend) of Texas and New Mexico. These areas seem to be the logical source of the material.

\section{Turquoise}

Turquoise beads, pendants, and even semiworked raw turquoise ore fragments have been found throughout northeastern Texas (Krieger 1946:207-208). Among the most significant was a necklace with beads and pendants from a juvenile burial at the Goss Farm (41FN12) in Fannin County (Housewright 1946:10). A turquoise pendant was reportedly found by Perino at the Holdeman site in Red River County (Timothy K. Perttula, personal communication 1995). At least two burials at the Sam Kaufman site yielded turquoise artifacts similar to those at Goss Farm (Harris 1953; Skinner et al. 1969). A substance thought to be turquoise was recovered from the Hatchel site (Darrell Creel, personal communication 1995). The William Young family has collected three turquoise artifacts from the Sanders site.

Turquoise is known from a larger area as well. It is reported from the Moore site (Fort Coffee focus) near Spiro, in the Arkansas River Valley of Oklahoma (Orr 1946; Bell 1947; Weigand $e t$ al. 1977:31); and from the Standridge site in the Ouachita Mountains of Arkansas (Early et al. 1988:130-131). It is reported from the Menard site of the Arkansas River near the Mississippi (note: This personal communication came from Richard Polhemus, and needs to be checked against Marvin Jeter and/or John House before it is entered as fact).

The turquoise recovered by Housewright (with the aid of Lester Wilson and George Sandefur) 


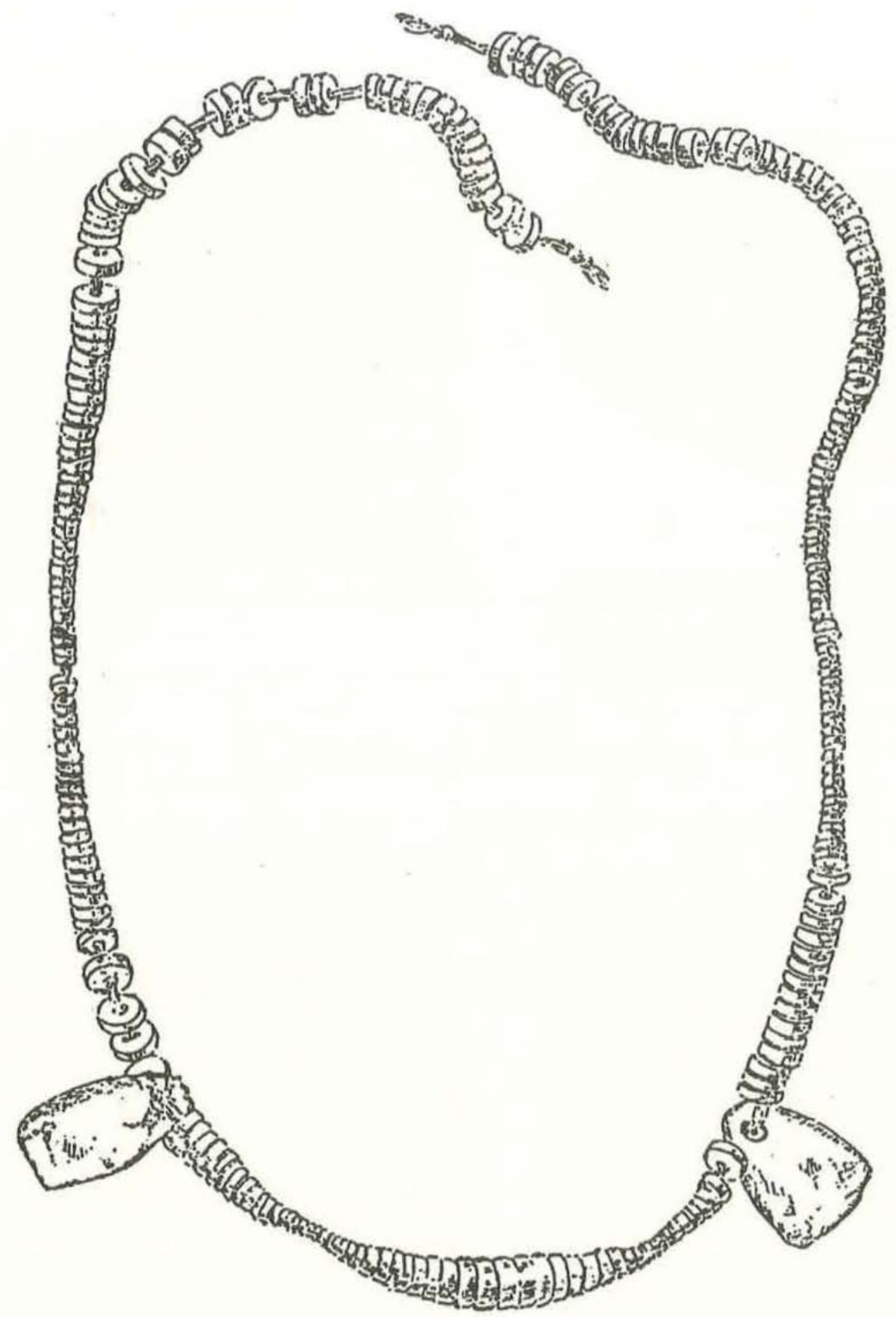

Figure 5. Turquoise Beads and Pendants from the Sam Kaufman Site on the Red River. 
from Goss farm, west of the Sanders Site across Bois d'Arc Creek is undoubtedly the most spectacular find in the region and contains more turquoise than anywhere else in the study area combined (Housewright 1946:10). The burial was that of a five to six year old child, placed in a gray clay; one red-filmed pottery sherd was present "below the plow zone." The beads were found around the head and shoulders "in short groups from 0.5-3.0 inches long." The necklace consisted of 260 small disc-shaped beads (diameter 3/32-5/32 inch) and two pendants (9/16 inch long, 6/16 inch and 5/16 inch wide, and 3/32 inch thick); which when joined form a string 10.25 inches long (Figure 4). They ranged in color from bright blue, to bluish green, to almost white.

At the Sam Kaufman site, Burial 8, a poorly preserved person of indeterminate sex, was placed in the village area east of the county road. Two shell-tempered vessels (not illustrated or catalogued?) were included as grave furniture, along with two small turquoise pendants and five turquoise beads "of the same type (Figure 5) as found by Rex Housewright in a burial on Goss Farm in Fannin County" (Harris 1953:59). Skeleton 17 in the shaft tomb at Sam Kaufman

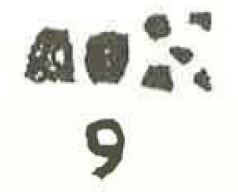

Figure 5. Turquoise beads and pendants from the Sam Kaufman Site (Harris 1953).

yielded 30 disc-shaped turquoise beads ( 3 - 5 $\mathrm{mm}$ diameter, $1 \mathrm{~mm}$ thick). In addition, this individual was buried with shell beads, conch shell inlays, shell cameos (human heads), shell gorgets, and pearl beads, and was accompanied with earspools. A radiocarbon date ( $c a .1400$ 1500) on this tomb has been obtained by the Texas Historical Commission, and will soon be reported (Timothy K. Perttula, personal communication 1995).

The turquoise in the Young collection was recovered from the Sanders site (Figure 6). These items include a small bead, a fragment of a pendant similar to those from Goss Farm and Sam Kaufman, and a piece of raw turquoise with incipient grinding on one surface.

\section{Turquoise Sourcing}

There have been remarkably few studies conducted on the sourcing of turquoise, with the assumption that all is derived from the Southwest. Two beads from a Caddoan burial at the Moore site near Spiro were sourced through trace element chemistry (neutron activation) to specimens from a Pueblo IV site in the Rio Grande valley of New Mexico (Weigand et al. 1977:31; Early et al. 1988:130-131).

In contradistinction, eight tiny turquoise beads found in the skull area of a burial from Feature
9 at the Standridge Site in Arkansas were sourced through trace element chemistry (neutron activation) to the Ouachita Mountains of Arkansas. Key trace elements include barium, which is apparently absent in southwestern turquoises (Early et al. 1988:130-131).

An excellent test of the Southwestern-Caddoan interaction would be the sourcing of the turquoise from Sanders, Sam Kaufman, and Hatchel. The Rio Grande-Northeast Texas trajectory is predicted. 


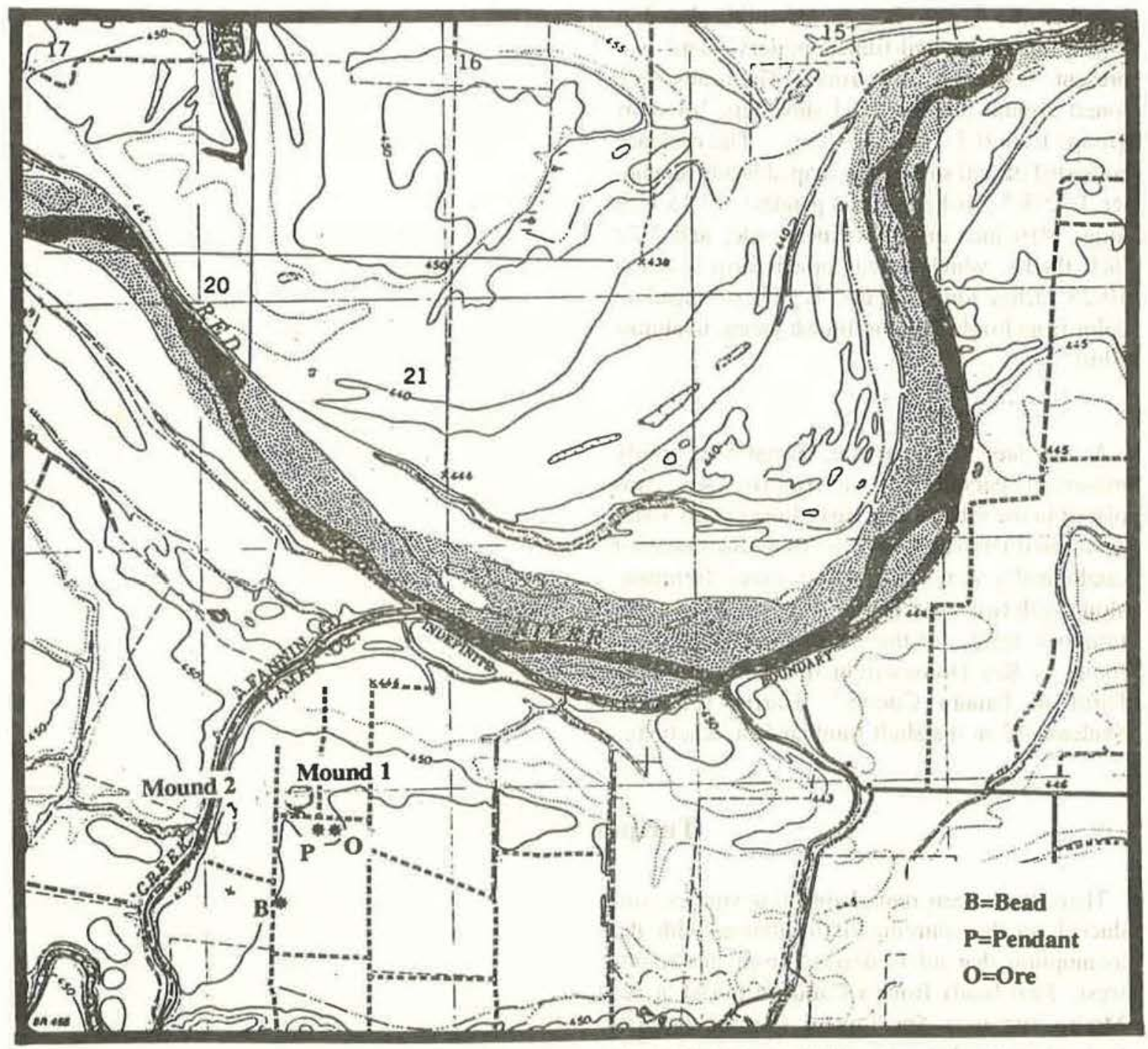

Figure 6. Location of the Turquoise Finds at the Sanders Site, Lamar County, Made by the Young Family. 


\section{Additional Evidence for Exchange}

Other evidence for direct exchange between the Southwest and the Texas Caddoan area was noted by Kreiger where Patton Engraved pottery sherds were recovered from Concepçion Focus houses in Presidio County on the Rio Grande, and Concepçion Focus arrow points were recovered from the Patton Site in Anderson County on the Trinity River (Kreiger 1946:209).

Although not directly related, a distinctive type of trade pendant, similar to the turquoise ones from sites along the Red River, was made by the Cahokia Illini ca. 1690-1750 (Walthall and Benchley 1987:30). These pendants are made from crushed blue glass beads, interlace with crushed white glass beads, which are re-melted and fused. The resulting material is polished and resembles turquoise in both color and appearance.

\section{Discussion}

The Sanders site and the Lower Rockwall site are strategically located at the frontier of the hypothesized Southwestern-Caddoan trading network that began $c a$. A.D. 950-(Kreiger 1946; Lorrain and Hoffrichter 1968) and apparently flourished until the 19th century. Analysis of avocational collections and the archaeological literature indicate three loci of Southwestern influences in Texas. Two of these appear to be related to 14th-century Puebloan expansions and interaction with pre-horse plains groups (extending as far as the Pratt Complex in Kansas (Hofman 1989), the third appears to be related to an earlier 10th century Caddoan interaction sphere possibly relating to trade in salt and bow wood for bison hides, fur, and meat. Caddoan ceramics have been noted in Plains (Baugh 1986) and southwestern Texas (Kelley 1939; Kelley et al. 1940) contexts dating to these periods. Both areas exhibit Southwestern trade items dating to the post-horse period ( $\mathrm{ca}$. 1680) when firearms apparently replace the bow wood, trade, further complicating the situation.

Another distributional correlation, which appears to be related, is the location of the socalled "Wylie focus pits" in comparison to these Southwestern trade erratics. The northernmost "Wylie focus pits" cluster along the East Fork Trinity River and are located within the zone of native stands of bois d'arc (Jurney 1994). The Lower
Rockwall site and the Sanders site are strategically placed at the northern and southern end of this stand, according to the same pattern as the trade erratics (Figure 1). The Richland/Chambers "Wylie focus pits" are located intermediate between the Patton site - where Concepçion complex artifacts were recovered - and the Lower Rockwall site, suggesting some type of strategic placement.

In conclusion, this exercise has called into focus an urgent need; that of proper curation of archaeological materials for future analyses. This applies to professionals as well as avocationals. Grave goods are required to be reburied in federal repositories, thereby losing the opportunity to source the beads. (Many private collectors are reluctant to donate to such federal repositories for this reason, money is another). Also, many avocation collections, such as Housewright's may eventually be sold on the auction block removing it farther from public access. Either way, the necklace from the Goss Farm site is one of the most phenomenal items in the southern Plains, indicating Southwestern trade and great reverence for a child, and it may pass to oblivion. The high incidence of turquoise and Southwestern pottery finds at the Sanders site and related sites along the Red River confirm a major role in Southwestern-Caddoan interaction. 


\section{References Cited}

Baugh, Timothy G. (editor)

1982 Edwards I (34BK2): Southern Plains Adaptations in the Protohistoric Period. Oklahoma Archaeological Survey, Studies in Oklahoma's Past 8. Norman.

1986 Current Trends in Southern Plains Archaeology. Plains Anthropologist Memoir 21.

Baugh, Timothy G. and F. E. Swenson 1980 Comparative Trade Ceramics: Evidence for the Southern Plains Macroeconomy. Oklahoma Anthropological Society. Hoffman Printing Co. Muskogee.

Bell, Robert E.

1947 Trade Materials at Spiro Mound as Indicated by Artifacts. American Antiquity 12(3):181-184.

1984a The Plains Villagers: The Washita River. In Prehistory of Oklahoma, edited by R. E. Bell, pp. 307-324. Academic Press, New York.

1984b Protohistoric Wichita. In Prehistory of Oklahoma, edited by R. E. Bell, pp. 363378. Academic Press, New York.

Bell, Robert E. and Tyler Bastian 1967 Preliminary Report Upon Excavations at the Longest Site, Oklahoma. In A Pilot Study of Wichita Indian Archaeology and Ethnohistory, assembled by R. E. Bell, E. B. Jelks, and W. W. Newcomb, pp. 119-127. National Science Foundation Final Report.

Bell, R. E., E. B. Jelks, and W. W. Newcomb 1967 A Pilot Study of Wichita Indian Archaeology and Ethnohistory. National Science Foundation Final Report.
Brooks, Robert L. 1989 Village Farming Societies. In From Clovis to Comanchero: Archeological Overview of the Southern Great Plains, edited by J. L. Hofman et al., pp. 71-90. Arkansas Archeological Survey Research Series 35. Fayetteville.

Bruseth, James E. 1987 Ceramic Artifacts. In The Bird Point Island and Adams Ranch Sites, edited by James E. Bruseth and William A. Martin, pp. 109-126. Richland Creek Technical Series Volume II. Archaeology Research Program, Southern Methodist University.

Creel, Darrell

1991 Bison Hides in Late Prehistoric Exchange in the Southern Plains. American Antiquity 56(1):40-49.

Early, Ann M., Barbara A. Burnett, and Daniel Wolfman

1988 Standridge: Caddoan Settlement in a Mountain Environment. Arkansas Archeological Survey Research Series 29. Fayetteville.

Flynn, Peggy 1986 Analysis of Test Excavations at the Zimms Site (34RM72), Western Oklahoma. In Current Trends in Southern Plains Archaeology, edited by Timothy G. Baugh. Plains Anthropologist Memoir 21:129-140.

Habich-Mauche, Judith A.

1987 Southwestern-Style Culinary Ceramics on the Southern Plains: A Case Study of Technological Innovation and CrossCultural Interaction. Plains Anthropologist 32:175-189.

Harris, R. K.

1953 The Sam Kaufman Site, Red River County, Texas. Bulletin of the Texas Arche- 
ological Society 24:43-63.

Harris, R.K., I.M. Harris, J.C. Blaine, and J. Blaine

1965 A Preliminary Archeological and Documentary Study of the Womack Site, Lamar County, Texas. Bulletin of the Texas Archeological Society 36:287-363.

Hayner, E. W.

1955 Another Puebloan Trade Sherd in East Texas. Bulletin of the Texas Archeological Society 26:245-248.

Hofman, Jack L.

1978 An Analysis of Surface Material from the Little Deer Site, 34CU10, of Western Oklahoma: A Further Investigation of the Wheeler Complex. Bulletin of the Oklahoma Anthropological Society 27:1-109.

1989 Protohistoric Culture History on the Southern Great Plains. In From Clovis to Comanchero: Archeological Overview of the Southern Great Plains, edited by J. L. Hofman et al., pp. 91-100. Arkansas Archeological Survey Research Series 35. Fayetteville.

Hofman, J. L., R. L. Brooks, J. S. Hays, D. W. Owsley, R. L. Jantz, M. K. Marks, and M. Manhein

1989 From Clovis to Comanchero: Archeological Overview of the Southern Great Plains. Arkansas Archeological Survey Research Series 35. Fayetteville.

Housewright, Rex

1941 A Multiple Burial in Lamar County. The Record, Dallas Archaeological Society 2:37-39.

1946 A Turquoise Bead Necklace. The Record 5(2):9-10.

Jeter, Marvin D., David H. Jurney, Jami J. Lockhart, and Frank F. Schambach 1994 OOP! The Osage Orange Project: A
Preliminary Report. Paper presented at the 36th Caddo Conference, Fayetteville, Arkansas.

Johnson, E., V. T. Holliday, M. J. Kaczor, and R. Stuckenrath

1977 The Garza Occupation at the Lubbock Lake Site. Bulletin of the Texas Archeological Society 48:83-109.

Jurney, David $\mathrm{H}$. 1994 The Original Distribution of Bois d'Arc. Part I: Texas. Caddoan Archeology Newsletter 5(2):6-13.

Kelley, J. Charles

1939 Archaeological Notes on the Excavation of a Pithouse near Presidio, Texas. El Palacio 46:221-234. Santa Fe.

Kelley, J. C. T. N. Campbell, and Donald J. Lehmer

1940 The Association of Archaeological Materials with Geological Deposits in the Big Bend Region of Texas. Sul Ross State Teachers College Bulletin 21 (3). Alpine, Texas.

Kreiger, Alex D.

1946 Culture Complexes and Chronology in Northern Texas. University of Texas Publication 4640. Austin.

Lintz, Chris

1986 Architecture and Community Variability Within the Antelope Creek Phase. Oklahoma Archaeological Survey, Studies in Oklahoma's Past 14. Norman.

Lorrain, Dessamae and Norma Hoffrichter 1968 The Lower Rockwall Site, Rockwall County, Texas. Report submitted to the National Park Service by the Salvage Project, Southern Methodist University, Dallas.

McIntyre, A. J. and D. E. McGregor 1982 A Petrographic Analysis of Southwestern Trade Vessel Recovered in Rockwall 
County, Texas. In Season One (1982) Mitigation of Prehistoric Archaeology in the Richland/Chambers Reservoir, Navarro and Freestone Counties, Texas: Interim Report, edited by A. J. McIntyre, pp. 513-520. Archaeology Research Program, Southern Methodist University.

Orr, K.G.

1946 The Archaeological Situation at Spiro, Oklahoma: A Preliminary Report. American Antiquity 11(4):228-256.

Prikryl, D.J.

1990 Lower Elm Fork Prehistory: A Redefinition of Culture Concepts and Chronologies Along the Trinity River, North Central Texas. Office of the State Archeologist, Texas Historical Commission, Report 37. Austin.

Schambach, Frank 1993 Some New Interpretations of Spiroan Culture History. In Archaeology of Eastern North America, Papers in Honor Stephen Williams, edited by J.B. Stoltman. Mississippi Department of Archives and History, Archaeological Report 25:187-230. Jackson.

Skinner, S.A., R.K. Harris, and K.M. Anderson (editors)

1969 Archaeological Investigations at the Sam Kaufman Site, Red River County, Texas. Southern Methodist University, Contributions in Anthropology. Dallas.

Spielmann, Katherine A.

1982 Inter-Societal Food Acquisition Among Egalitarian Societies: An Ecological Study of the Plains/Pueblo Interaction in the American Southwest. Ph. D. dissertation, Anthropology, University of Michigan.

Thurman, J. Peter

1990 Archeology of the Cypress Creek Drainage Basin Northeastern Texas and
Northwestern Louisiana. Studies in Archeology 5, Texas Archeological Research Laboratory, University of Texas, Austin.

Walthall, John A., and Elizabeth D. Benchley 1987 The River L-Abbe Mission: A Colonial Church for the Cahokia Illini. Illinois Historic Preservation Agency, Springfield.

Wedel, Waldo R.

1982 Further Notes on Puebloan-Central Plains Contacts in Light of Archaeology. In Pathways to Plains Prehistory: Anthropological Perspectives of Plains Natives and Their Pasts, edited by D. G. Wyckoff and J. L. Hofman, pp. 145-152. Cross Timbers Press, Duncan.

1986 Central Plains Prehistory: Holocene Environments and Culture Change in the Republican River Basin. University of Nebraska Press, Lincoln.

Weigand, Phil C., Garman Harbottle, and Edward V. Sayre

1977 Turquoise Sources and Source Analysis: Mesoamerica and the Southwestern U.S.A. In Exchange Systems in Prehistory, edited by Timothy K. Earle and Jonathon E. Ericson, pp. 15-34. Academic Press, New York.

Wilson, Diane

1993 Incidence of Degenerative Joint Disease Among the Sanders Site (41LR2) Population. Paper presented at the 35 th Caddo Conference, Norman, Oklahoma.

1994 Division of Labor and Stress Loads at the Sanders Site (41LR2), Lamar County, Texas. Bulletin of the Texas Archeological Society 65:129-160.

Wright, George T.

1943 A Pueblo Pot Found Near Paris, Texas. Texas Archaeological and Paleontological Society Bulletin 15:92-96. 